\title{
INTEGRASI RANTAI PASOK KOMODITAS SAYUR ANTARA PRODUKTIVITAS TRANSPORTASI, FARMER SHARE DAN PENGUKURAN KEUNTUNGAN PADA WILAYAH SULAWESI UTARA
}

\author{
David Oscar Simatupang \\ **Staf Pengajar FAPERTA UNMUS-Merauka, Email: simatupangdavid@yahoo.com
}

\begin{abstract}
ABSTRAK
Penelitian ini bertujuan untuk menganalisis Integrasi rantai pasok dalam kemitraan yang efektif pada tingkat petani itu sendiri dalam wadah gapoktan, karakteristik dan produktifitas transportasi, dan pengukuran efesiensi margin keuntungan dan farmer shere pada tingkat pelaku rantai pasok dari Minahasa Selatan pada kecamatan Modoinding (sentra komoditi sayur) ke wilayah kota Manado melalui pelanggan pasar tradisional dan pasar modern. Metode pengolahan dan analisis data deskriptif kualitatif dan kuantitatif dengan membagi tiga jenis sayur yaitu Kentang, Kubis dan Tomat. Lokasi penelitian dipilih secara proporsive sampling yaitu kecamatan Modoinding dan kota Manado. Hasil penelitian menunjukkan integrasi rantai pasok dalam hal ini kemitraan yang efektif terjadi pada tingkat petani itu sendiri dalam wadah Gapoktan. Pada Jalur yang lebih efesien adalah jalur 1, namun lebih efektif pada jalur 2 dengan efesiensi rasio produktifitas $42 \%$ dan margin keuntungan tertinggi terdapat pada pedagang pengumpul besar. Untuk tingkat petani, komoditi sayur buah (Tomat) memiliki R/C yang tinggi dan efesiensi farmer share tertinggi pada pedagang pengumpul kecil dan juga pedagang perantara.
\end{abstract}

Kata Kunci: Integritas Rantai Pasok, Produktifitas Transportasi, Margin Keuntungan dan Farmer Shere

\section{PENDAHULUAN}

\subsection{Latar Belakang}

Salah satu pengahasil hortikultura di Indonesia adalah Sulawesi Utara dengan sentra komoditi sayur pada wilayah Kabupaten Minahasa Selatan, dengan luas lahan $7.574 \mathrm{Ha}$ dan jumlah produksi 114.115 Ton pada tahun
2011 (data olahan BPS 2012 Sulawesi Utara) maka perkembangan komoditi hortikultura di Sulawesi Utara sangat menunjang. Namun terjadi fluktuasi yang cenderung terjadi penurunan dalam jumlah konsumsi masyarakat Sulawesi Utara pada tiga tahun terakhir ini, hal tersebut dapat dilihat pada Tabel 1.

Tabel 1. Rata-rata Konsumsi Kalori dan Protein Perkapita, Luas Lahan, Rata-rata Produksi dan Jumlah Produksi.

\begin{tabular}{cccccc}
\hline \multirow{2}{*}{ Years } & \multicolumn{2}{c}{ Konsumsi Sayur } & \multicolumn{2}{c}{ Lahan } & Sayur \\
\cline { 2 - 6 } & Kalori $($ gram $)$ & Protein $($ gram $)$ & Luas Lahan $(\mathrm{Ha})$ & Luas Panen $(\mathrm{Ha})$ & Produksi $($ Ton) \\
\hline 2009 & 49,23 & 3,47 & 7.566 & 7.520 & 149.456 \\
2010 & 41,00 & 2,86 & 6.866 & 7.019 & 129.258 \\
2011 & 37,41 & 2,58 & 7.574 & 7.589 & 144.115 \\
\hline
\end{tabular}

(Sumber : Data BPS Sulawesi Utara tahun 2012) 
Hal ini dikhawatirkan banyak petani penghasil sayur di daerah Minahasa Selatan yang tidak mampu menarik pembeli kompetitif (Gunatilake, 1992) dan juga banyak lahan pertanian yang terletak di daerah relatif terpencil, dengan jarak yang cukup jauh dari jalan membuat akses ke pasar untuk bersaing harga lebih sulit (Hettige dan Senanayake, 1992; Kodithuwakku, 2000; Schermerhon, 1986) selain akses pasar yang yang jauh, hal ini memerlukan waktu hasil komoditi sayur untuk mencapai pasar atau dalam pemenuhan ketersediaan pasar sehingga menimbulkan kendala dalam rantai pasokan sayuran dalam perencanaan, sosialisasi, dan pengiriman, (Morgan et all, 2004)

Dengan melihat ketersedian produksi yang tinggi dan juga didukung luas lahan yang produktif seharusnya dapat meningkatkan permintaan konsumsi secara signifikan pada masyrakat Sulawesi Utara khususnya kota Manado sebagai pangsa pasar yang ideal karena memiliki pasar modern dan juga pasar tradisional sebagai lembaga pemasarannya, sehingga dalam penyerapan dan rantai pasoknya akan produksi sayur lebih cepat. Hal ini juga dipengaruhi oleh perilaku konsumen masyarakat kota dimana kebutuhan akan produk sayur yang berkualitas dan gaya hidup sehat semangkin tinggi. Hingga diperlukan keterpaduan terhadap alur pasokan (rantai pasok) ke wilayah pangsa pasar yang ideal dan juga dengan melihat karakteristik tanaman hortikultura / sayur itu sendiri.

Dengan melihat kendala atau masalah dan juga beberapa penelitian sebelumnya, maka perlunya penelitan Rantai Pasok keterpaduan antara produktifitas dalam transportasi, farmer shere dan pengukuran keuntungan terhadap komoditas hortikultura khususnya di Sulawesi utara

\section{Metode Penelitian}

\subsection{Pendekatan dan Jenis Penelitian}

Pendekatan Penelitian adalah penelitian deskriptif, yakni untuk mendeskripsikan kegiatan rantai pasok sayur dilapangan oleh petani sayur, pedagang pengumpul, pedagang perantara di Minahasa Selatan dan pedagang pada pasar tradisonal dan modern sebagai pelanggan dengan pertimbangan jumlah pasokan sayur yang tinggi atau banyak di kota Manado, dimana jenis penelitian yang digunakan adalah metode penelitian survey (survey deskriptif.

\subsection{Teknik Analisis Data}

Data yang diperoleh dari hasil penelitian kemudian diolah dan dianalisis menggunakan dua metode analisis data yaitu:

\subsubsection{Analisis Deskripsi Kualitatif}

Yaitu memberikan gambaran pertanian sayur di wilayah Minahasa Selatan, dengan melihat sistem jaringan rantai pasok atau penyaluran hasil produksi dari petani ke pedagang pengumpul ataupun langsung ke konsumen di wilayah kota Manado melalui tempat pemasaran yaitu pasar tradisional dan modern dimana didalamnya terdapat proses inventory, ke dalam bentuk tabel, gambar atau grafik, namun belum mengambil putusan terhadap hipotesis penelitian ini.

\subsubsection{Analisis Deskripsi Kuantitatif}

\section{a. Farmer's Share}

Adalah perbandingan harga yang dibayar oleh konsumen akhir yang biasanya dinyatakan dalam persentase. Farmer's Share mempunyai hubungan terbalik (negative) dengan marjin pemasaran, sehingga semangkin tinggi margin pemasaran maka makin rendah yang diterima petani. Farmer's Share dapat dirumuskan sebagai berikut :

$$
\text { Fsi }=\frac{\text { Pf }}{\text { Pr }} \times 100 \%
$$

Dimana :

$$
\begin{aligned}
\text { Fsi }= & \begin{array}{l}
\text { Persentase yang diterima petani } \\
(\%)
\end{array} \\
P_{f}= & \begin{array}{l}
\text { Harga di tingkat atau yang } \\
\text { diterima petani }(\mathrm{Rp} / \mathrm{kg})
\end{array} \\
\mathrm{P}_{\mathrm{r}}= & \begin{array}{l}
\text { Harga yang dibayarkan oleh } \\
\text { konsumen akhir }(\mathrm{R} / \mathrm{kg})
\end{array}
\end{aligned}
$$

\section{b. Analisis efesien rantai pasokan.}

Efesiensi ini diukur dengan cara membandingkan biaya total tranportasi, dan harga berdasarkan alokasi optimalnya (Tunggal, 2008). Alokasi optimal adalah alokasi yang memberikan biaya minimal dimana dapat dikendalikan dengan menggunakan rasio produktivitas. 
Produktivitas $=\frac{\text { Pengukuran Output }}{\text { Pengukuran Input }}$

Untuk rasio produktivitas Transportasi termasuk :

Ton - miles yang dikirim
$\begin{gathered}\text { Total biaya transportasi aktual } \\ \text { Stop Served }\end{gathered}$
$\begin{gathered}\text { Total Biaya transportasi aktual } \\ \text { Pengiriman ke tujuan }\end{gathered}$
$\frac{\text { Total biaya transportasi aktual }}{}$

III. Hasil dan Pembahasan

3.1. Integritas Rantai Pasok

Dapat dilihat pada Gambar 1 struktur integrasi rantai pasok modoinding ke pasar tradisional dan modern kota Manado terdapat tiga hubungan yang membentuk integrasi rantai pasok sayur yaitu berdasarkan persentase tingkat kemitraan, informasi kebutuhan pasokan, dan kesepakatan harga.
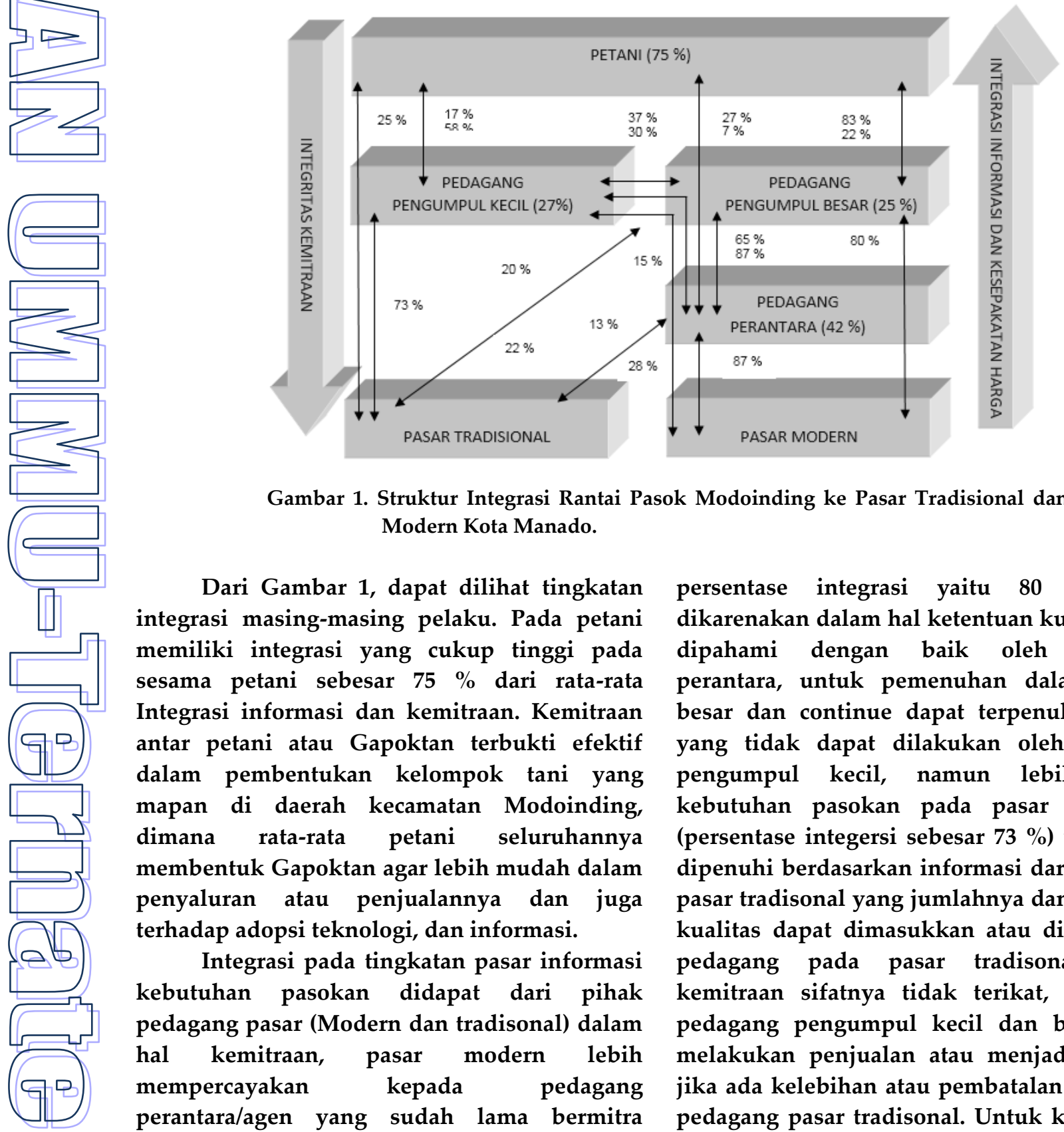

Gambar 1. Struktur Integrasi Rantai Pasok Modoinding ke Pasar Tradisional dan Modern Kota Manado.

Dari Gambar 1, dapat dilihat tingkatan integrasi masing-masing pelaku. Pada petani memiliki integrasi yang cukup tinggi pada sesama petani sebesar $75 \%$ dari rata-rata Integrasi informasi dan kemitraan. Kemitraan antar petani atau Gapoktan terbukti efektif dalam pembentukan kelompok tani yang mapan di daerah kecamatan Modoinding, dimana rata-rata petani seluruhannya membentuk Gapoktan agar lebih mudah dalam penyaluran atau penjualannya dan juga terhadap adopsi teknologi, dan informasi.

Integrasi pada tingkatan pasar informasi kebutuhan pasokan didapat dari pihak pedagang pasar (Modern dan tradisonal) dalam hal kemitraan, pasar modern lebih mempercayakan kepada pedagang perantara/agen yang sudah lama bermitra dengan pasar modern dengan integrasi persentase yaitu $87 \%$ begitu juga sebagian besar pada pedagang pengumpul besar dengan persentase integrasi yaitu $80 \%$, ini dikarenakan dalam hal ketentuan kualitas telah dipahami dengan baik oleh pedagang perantara, untuk pemenuhan dalam jumlah besar dan continue dapat terpenuhi. Hal ini yang tidak dapat dilakukan oleh pedagang pengumpul kecil, namun lebih kepada kebutuhan pasokan pada pasar tradisional (persentase integersi sebesar $73 \%$ ) yang dapat dipenuhi berdasarkan informasi dari pedagang pasar tradisonal yang jumlahnya dan ketentuan kualitas dapat dimasukkan atau diambil oleh pedagang pada pasar tradisonal. Untuk kemitraan sifatnya tidak terikat, dalam arti pedagang pengumpul kecil dan besar dapat melakukan penjualan atau menjadi pengecer jika ada kelebihan atau pembatalan dari pihak pedagang pasar tradisonal. Untuk kesepakatan harga telah ditentukan dari pihak pedagang, tetapi untuk komoditi yang di ecer kesepakatan 


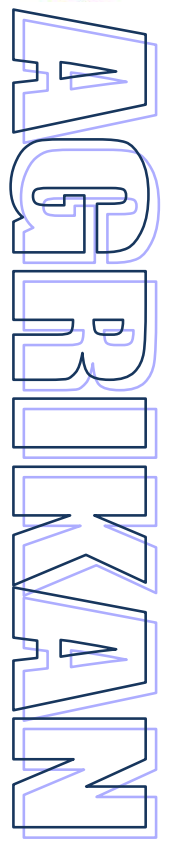

berdasarkan kedua belah pihak (terjadi tawarmenawar).

\subsection{Karakteristik dan Produktifitas Tranportasi}

Pada pengiriman dari wilayah Kecamatan Modoinding ke wilayah kota Manado, para pedagang menggunakan dua jalur yang berbeda berdasarkan karakteristik jalan yaitu :
Jalur pertama yaitu : Kecamatan Modoinding Kecamatan Tomapaso Baru - Kecamatan Amurang - Manado (Gamar 2). Pada jalur kedua yaitu : Kecamatan Modoinding - Kota Kotamobagu - Kecamatan Tenga - Kecamatan Tumpaan - Kota Manado (Gambar 3).
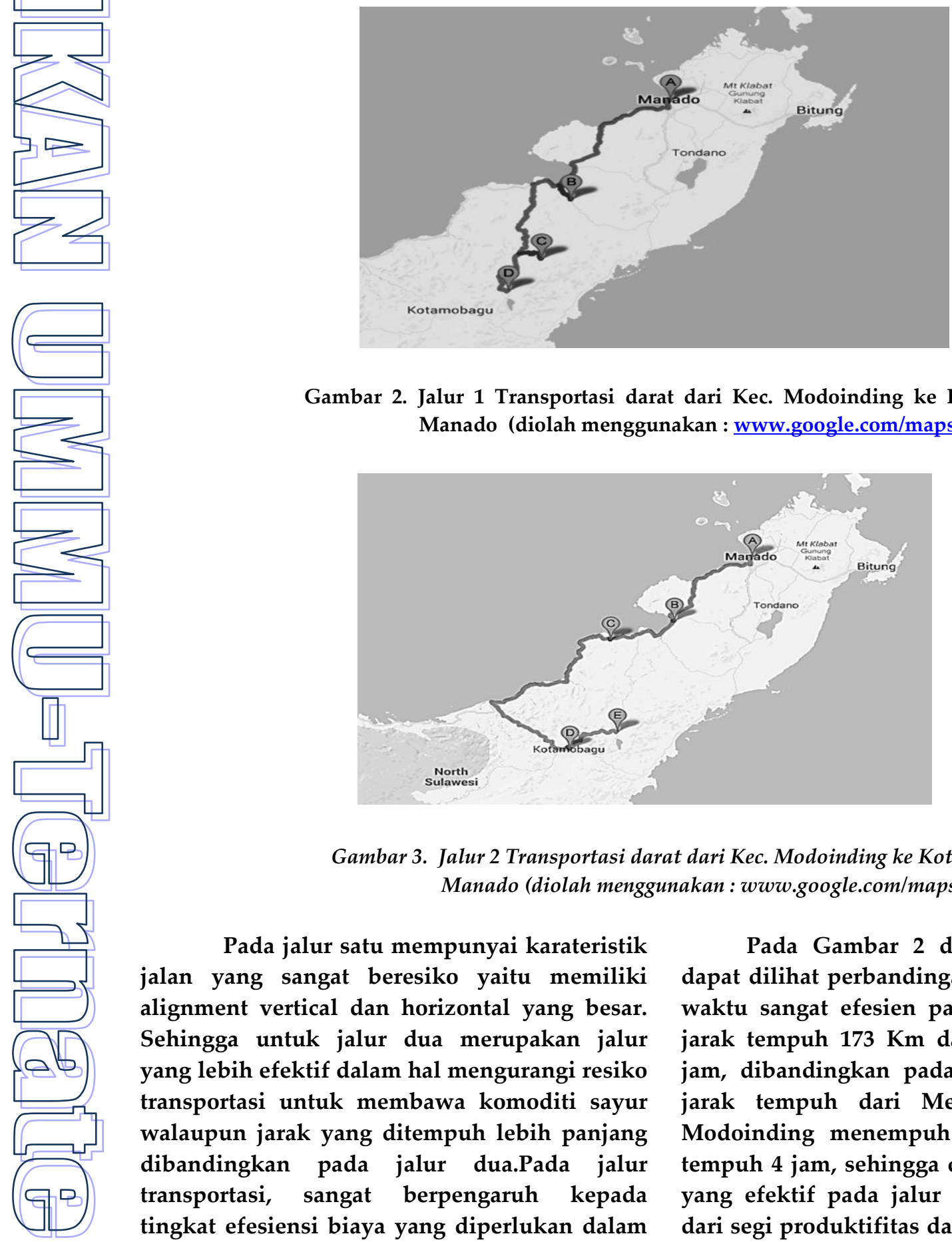

Gambar 2. Jalur 1 Transportasi darat dari Kec. Modoinding ke Kota Manado (diolah menggunakan : www.google.com/maps)

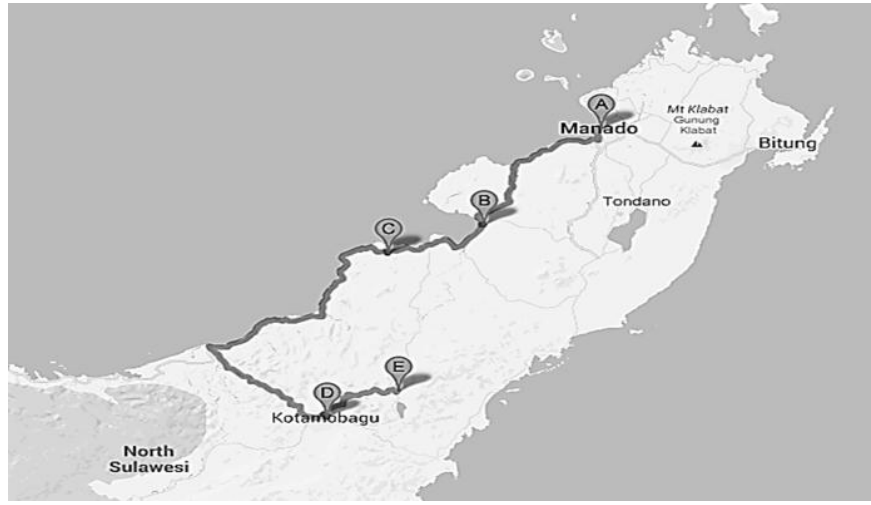

Gambar 3. Jalur 2 Transportasi darat dari Kec. Modoinding ke Kota Manado (diolah menggunakan : www.google.com/maps).

Pada jalur satu mempunyai karateristik jalan yang sangat beresiko yaitu memiliki alignment vertical dan horizontal yang besar. Sehingga untuk jalur dua merupakan jalur yang lebih efektif dalam hal mengurangi resiko transportasi untuk membawa komoditi sayur walaupun jarak yang ditempuh lebih panjang dibandingkan pada jalur dua.Pada jalur transportasi, sangat berpengaruh kepada tingkat efesiensi biaya yang diperlukan dalam proses perpindahan komoditi sayur dari wilayah Kecamatan Modoinding ke wilayah manado.
Pada Gambar 2 dan Gambar 3 diatas, dapat dilihat perbandingan dari segi jarak dan waktu sangat efesien pada jalur satu dengan jarak tempuh $173 \mathrm{Km}$ dan waktu tempuh 3,5 jam, dibandingkan pada jalur kedua dengan jarak tempuh dari Menado ke kecamatan Modoinding menempuh $210 \mathrm{~km}$ dan waktu tempuh 4 jam, sehingga dalam pemilihan jalur yang efektif pada jalur satu. Untuk efesiensi dari segi produktifitas dapat dilihat pada Tabel 12, dimana pada jalur dua lebih efesien dengan tingkat rasio produktifitas $42 \%$ lebih tinggi dibandingkan dengan jalur pertama yaitu $31 \%$. 
Dari hasil analisis pada Tabel 3 menunjukan keuntungan disetiap rantai berbeda-beda, untuk komoditi kentang, margin keuntungan tertinggi terdapat pada wilayah rantai pasok pedagang pengumpul besar. Dengan biaya $R p 580$ tiap kilogramnya, pengumpul besar dapat menghasilkan keuntungan untuk setiap kilogramnya sebesar 170 rupiah. Hal ini disebabkan oleh karena system pembelian dari pihak pedagang pengumpul besar yang sifatnya borongan dari pihak petani. Sehingga harga pembelian dari pihak petani dapat ditekan, ditambah dengan jenis kendaraan yang digunakan mempunyai muatan yang besar ketimbang pedagang pengumpul kecil. Begitu juga dengan komoditi sayur kubis dan tomat yang mempunyai marjin keuntungan masing-masing sebesar Rp. 267 dan Rp. 313,34 tiap kilogram yang dijual oleh pedagang pengumpul besar. Hal ini juga disebabkan oleh penjualan keluar daerah yang mempunyai harga tinggi dan permintaan yang besar.

Tabel 2. Efesiensi Produktifitas Transportasi

\begin{tabular}{|c|c|c|c|c|}
\hline Jalur & $\begin{array}{l}\text { Total Biaya } \\
\text { (Rp/bulan) }\end{array}$ & $\begin{array}{c}\text { Jarak Tempuh } \\
(\mathrm{Km})\end{array}$ & $\begin{array}{c}\text { Jumlah Muatan } \\
\text { (Kg) }\end{array}$ & $\begin{array}{c}\text { Rasio } \\
\text { Produktifitas }\end{array}$ \\
\hline jalur & $4,750,000$ & 173 & 8500 & $31 \%$ \\
\hline jalur 2 & $4,262,000$ & 210 & 8500 & $42 \%$ \\
\hline
\end{tabular}

(Sumber Data : Olahan Data Primer)

Tabel 3. Analisis Biaya Rantai Pasok Komoditi Sayur

\begin{tabular}{|c|c|c|c|c|}
\hline No & Uraian & $\begin{array}{c}\mathrm{Rp} / \mathrm{Kg} \\
\text { (Kentang) }\end{array}$ & $\begin{array}{c}\mathrm{Rp} / \mathrm{Kg} \\
\text { (Kubis) }\end{array}$ & $\begin{array}{c}\mathrm{Rp} / \mathrm{Kg} \\
\text { (Tomat) }\end{array}$ \\
\hline \multirow[t]{6}{*}{1} & Harga jual Petani & 2900 & 1250 & 5000 \\
\hline & Biaya & 65 & 54,2 & 43,3 \\
\hline & Pengepakan & 60 & 50 & 40 \\
\hline & Transportsi & 1,0 & 1,0 & 1,0 \\
\hline & Bongkar Muat & 0 & 0 & 0 \\
\hline & Tenaga Kerja & 4 & 3 & 3 \\
\hline \multirow[t]{8}{*}{2} & Harga beli pedagang pengumpul kecil & 2900 & 1250 & 5000 \\
\hline & Harga Jual pedagang pengumpul kecil & 3600 & 1500 & 5700 \\
\hline & Biaya & 230 & 191,6 & 153,7 \\
\hline & Pengepakan & 0 & 0 & 0 \\
\hline & Transportsi & 10 & 8,3 & 6,7 \\
\hline & Bongkar Muat & 0 & 0 & 0 \\
\hline & Tenaga Kerja & 220 & 183,3 & 147 \\
\hline & Margin Keuntungan & 70 & 58,4 & 546,3 \\
\hline \multirow[t]{8}{*}{3} & Harga beli pedagang pengumpul besar & 3000 & 1250 & 5000 \\
\hline & Harga Jual pedagang pengumpul besar & 3750 & 2000 & 5700 \\
\hline & Biaya & 580 & 483 & 386,66 \\
\hline & Pengepakan & 100 & 83,33 & 67,67 \\
\hline & Transportsi & 40 & 33,33 & 27,67 \\
\hline & Bongkar Muat & 220 & 183,33 & 146,67 \\
\hline & Tenaga Kerja & 220 & 183,33 & 147,67 \\
\hline & Margin Keuntungan & 170 & 267 & 313,34 \\
\hline \multirow[t]{6}{*}{4} & Harga beli pedagang perantara & 3000 & 1250 & 5000 \\
\hline & Harga Jual pedagang perantara & 3750 & 2000 & 5700 \\
\hline & Biaya & 626,7 & 522,2 & 417,7 \\
\hline & Pengepakan & 120 & 100 & 80 \\
\hline & Transportsi & 6,7 & 5,5 & 4,4 \\
\hline & Bongkar Muat & 200 & 166,67 & 133,33 \\
\hline
\end{tabular}




\begin{tabular}{rlrrr}
\hline & Tenaga Kerja & 300 & 250 & 200 \\
& Margin Keuntungan & 123,3 & 227,8 & 282,3 \\
& Harga beli pedagang pasar tradisional & 3750 & 1800 & 5500 \\
& Harga Jual pedagang pasar tradisional & 4200 & 2500 & 6500 \\
& Harga beli pedagang pasar Modern & 4200 & 2500 & 6500 \\
& Harga Jual pedagang pasar Modern & 11500 & 7100 & 9000 \\
\hline
\end{tabular}

(Sumber Data : Olahan Data Primer)

Untuk wilayah rantai pasok petani, dapat dilihat bahwa pada komoditi sayur buah (tomat) memiliki R/C yang tinggi yaitu 15,7 yang artinya komoditi tomat tingkat efesien ekonomi yang merupakan daya saing ekonomi yang lebih baik dibandingkan dengan sayur kentang yang $R / C$ sebesar 2,3 dan $R / C$ kubis sebesar 0,35 . Dalam hal ini imbangan biayapenerimaan lebih baik pada komoditi Tomat. Sehingga ditingkat rantai pasok petani, lebih lebih efesien untuk menanam sayur tomat dan kentang, manakala nilai rasio sama dengan atau $>$ 1. Untuk lebih jelas dapat dilihat pada Lampiran 4 untuk pada masing-masing komoditi.

\subsection{Farmer shere}

Farmer shere dalam hal ini merupakan salah satu tolak ukur efesiensi dalam rantai pasok, dimana semangkin tinggi tingkat persentase farmer shere yang diterima petani maka makin efesien yang diterima petani atau dengan kata lain semangkin efesien rantai pasok tersebut. Dari data pada Tabel 4 dapat dilihat bahwa terdapat farmer share tertinggi pada komoditi kentang adalah pada wilayah rantai pasok pedagang pengumpul kecil dan juga pedagang perantara sebesar 80,56 persen, yang berarti petani menerima 80,56 persen dari harga yang dibayarkan konsumen. Dan untuk komoditi sayur kubis, farmer shere tertinggi terdapat pada wilayah saluran pedagang pengumpul kecil sebesar 72,13 persen atau bisa dikatakan petani menerima sebesar 72,13 persen dari harga yang dibayarkan oleh konsumen pedagang pengumpul kecil. Dan untuk komoditi tomat tertinggi terdapat pada wilayah pedagang pengumpul kecil sebesar 90,91 persen, atau dapat dikatakan juga bahwa petani tomat mendapat bagian harga jualnya sebesar 90,91 persen.

\section{PENUTUP}

Berdasarkan hasil dan pembahasan, maka dapat ditarik kesimpulan yaitu sebagai berikut : Efektifitas dan efesiensi pelaku rantai pasok komoditi sayur untuk keseluruhan konfigurasi untuk pasar modern terdapat pada pedagang pengumpul besar yang memiliki integrasi tertinggi pada rantai pasok dan untuk pasar tradisional adalah pedagang pengumpul kecil. Untuk jalur transportasi pada kedua jenis pasar yang lebih efesien untuk jarak adalah jalur satu namun dari produktifitas transportasi adalah jalur dua. Pada efektifitas untuk resiko, jalur dua lebih baik daripada jalur satu. Efesiensi untuk margin keuntungan tertinggi terdapat pada wilayah rantai pasok pedagang pengumpul besar. Untuk tingkat petani, komoditi sayur buah (tomat) memiliki efektifitas tinggi dengan $\mathrm{R} / \mathrm{C}$ sebesar 15,7 dan efesiensi farmer share tertinggi pada komoditi kentang pada wilayah rantai pasok pedagang pengumpul kecil dan juga pedagang perantara sebesar 80,56 persen 
Tabel 24. Nilai yang diterima oleh Produsen pada masing-masing tingkat Rantai Pasok

\begin{tabular}{|c|c|c|c|c|}
\hline Saluran Rantai Pasok & $\begin{array}{c}\text { Jenis } \\
\text { Komoditi }\end{array}$ & $\begin{array}{l}\text { Harga di tingkat } \\
\text { Petani (Rp/Kg) }\end{array}$ & $\begin{array}{c}\text { Harga di tingakat } \\
\text { penjual (Rp/Kg) }\end{array}$ & $\%$ \\
\hline \multirow[t]{3}{*}{ Pedagang pengumpul Kecil } & Kentang & 2900 & 3600 & $80.56 \%$ \\
\hline & Kubis & 1250 & 1733 & $72.13 \%$ \\
\hline & Tomat & 5000 & 5500 & $90.91 \%$ \\
\hline \multirow[t]{3}{*}{ Pedagang pengumpul Besar } & Kentang & 2900 & 3800 & $76.32 \%$ \\
\hline & Kubis & 1250 & 2000 & $62.50 \%$ \\
\hline & Tomat & 5000 & 5700 & $87.72 \%$ \\
\hline \multirow[t]{3}{*}{ Pedagang Perantara } & Kentang & 2900 & 3600 & $80.56 \%$ \\
\hline & Kubis & 1250 & 2400 & $52.08 \%$ \\
\hline & Tomat & 5000 & 6500 & $76.92 \%$ \\
\hline \multirow[t]{3}{*}{ Pasar Tradisional } & Kentang & 2900 & 4200 & $69.05 \%$ \\
\hline & Kubis & 1250 & 2500 & $50.00 \%$ \\
\hline & Tomat & 5000 & 6500 & $76.92 \%$ \\
\hline \multirow[t]{3}{*}{ Pasar Modern } & Kentang & 2900 & 11500 & $25.22 \%$ \\
\hline & Kubis & 1250 & 7100 & $17.61 \%$ \\
\hline & Tomat & 5000 & 9000 & $55.56 \%$ \\
\hline
\end{tabular}

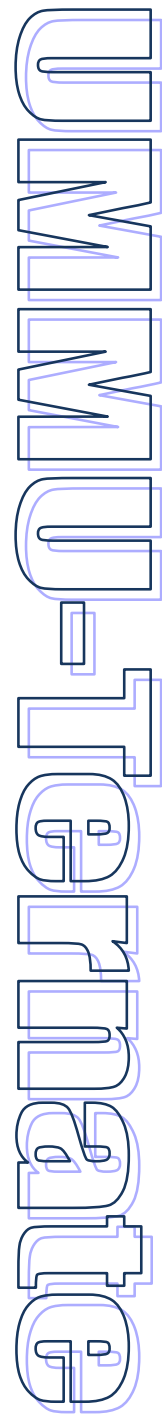

(Sumber Data : Olahan Data Primer)

\section{DAFTAR PUSTAKA}

Ballou, R. H. (2004). Bussiness Logistics Supply Chain Management, fifth edition. Upper Saddle River, NJ: Pearson Pretice Hall,Inc.

Best, R. J. (2000). Market-Based Management : STRATEGIES FOR GROWING CUSTOMER VALUE AND PROFITABILITY Second Edition. United States of America: Prentince-Hall, Inc.

Bongiwe G Xaba, M. B. (2013). An Analysis of the Vegetables Supply Chai in Swaziland. Sustainable Agriculture Research, Vol.2 No.2.

BPS. (2009-2011). Produksi Tanaman Sayuran dan Buah-buhan, di Sulawesi Utara. Manado: Badan Pusat Statistik Sulawesi Utara.

Chan, K. (2009). Integration of Small Farmers into Horticultural Chainsin Asia and Pacific Region. Bangkok: Food and Agriculture Organization of the United Nations, Regional Office for Asia and The Pasific.

Chopra S, P. (2007). Supply Chain Management, Planning and Operation. Pearson Prentice Hall.

Danfar. (2009). Bauran Pemasaran (Marketing Mix). http://dansite.wordpress.com/ 2009/04/05/bauran- pemasaran-marketing-mix/: Di akses pada tanggal 29 November 2011.

EQ, Z. M. (2009). Mengurai Variabel hingga Instrumentasi. Yogyakarta: Graha Ilmu.

Fateta. (1991). Studi Pengembangan Agroindustri Hasil Olahan Hortikultura. Bogor: Institut Pertanian Bogor.

Gany, R. A. (2012). Ilmu Ekonomi Pertanian dan Sumberdaya. Makassar: identitas Universitas Hasanuddin.

Gumbira E Sa'id, A. H. (2001). Manajemen Agribisnis. Indonesia: Ghali Indonesia.

Gunatilake, G. P. (1992). Rural Poverty in Sri Lanka : Priority Issues and Policy Measures. Asian Development Review, 10.

Gusli, S. (2013). Penulisan dan Publikasi Ilmiah Bidang Agro-SAins : Tesis, Disertasi dan Artikel. Makassar: identitas Universitas Hasanuddin.

Hadi, P. (2011, Maret 15). Manajemen Operasional "Just In Time". Retrieved from http://www.hadiptd.blogspot.com

Hadiguna, R. M. (2007). Alokasi pasokan berdasarkan produk unggulan untuk rantai pasok sayuran segar. Jurnal Teknik Industri, Nomor 2 Volume 9. 
Hanafie, R. (2010). Pengantar Ekonomi Pertanian. Yogyakarta: CV.Andi Offset.

Helzer Jay, B. (2004). Operation Management, Seventh Edition. USA: Pearson Prentice Hall,Inc.

Hettige, S. T. (1992). Highland Vegetable Production and Marketing Systems. A report prepered for Agriculture Cooperative Development International/USAID.

Husnan, M. D. (1998). MANAJEMEN KEUANGAN TEORI DAN PENERAPAN (KEPUTUSAN JANGKA PENDEK). YOGYAKARTA: BPFE-YOGYAKARTA.

Jeevika Weerahewa, M. K. (2004). Analysis of Vegatable Supply Chain of Supermarkets in Sri Lanka. Sri Lankan Journal of Agricultural Economic, Vol.6 No.1.

Kementrian Pertanian, M. P. (2012). Evaluasi Kinerja Tahun 2011 dan Rencana Perbaikan Kinerja Tahun 2012. Jakarta: Rakernas Pembangunan Pertanian 2012.

Kottler, P. (1999). Manajemen Pemasaran. Jakarta: Erlangga.

Laela, M. N. (2011). Rancangan Pengukuran Kinerja Rantai Pasokan Minyak Akar Wangi di Kabupaten Garut dengan Pendekatan Green Supply Chain Operation Reference. Bogor.

Lu, D. D. (2011, August 8). Fundamental of Supply Chain. Retrieved from bookboon.com: http://www.bookboon.com

Lukman, S. (2001). Paradigma Baru Pengembangan Pertanian, Suatu Tinjauan Sosiologis. Yogyakarta: Kanisius.

Manoshi Perera, S. S. (2004). Analysis of Vegatable Supply Chains of Supermarket in Sri Lanka. Sri Lankan Journal of Agricultural Economics, Vol.6 No.1.

Mohammad, F. (2010, july 5). Just In Time (JIT) dan Filosofinya. Retrieved from http://www.mamayukero.wordpress.com

Pusat Data dan Sistem Informasi Pertanian, K. P. (2012). Sektor Pertanian. Statistik Makro, Volume 4 No.2.

Rismayani. (2007). Analisis Saluran Distribusi Sebagai Penentu Harga dan Laba Pada Produk Hasil Pertanian Sayuran Buah Tomat. Jurnal Wawasan, Volume 13 Nomor 1.

Robert B. Hanfield, E. L.-J. (2002). Transforming Supply Chain Into Integreted Velue Systems. Upper Saddle River, New Jersey: Prantice Hall, Inc.

Schermerhon, R. (1986). A Comparative Analysis of Fruit and Vegetable Marketing in Developing Countries. GTS Report, Postharvest Institute for Perishables/USAID, Vol.82.

Sihombing, L. (2005). Analisis Tataniaga Kentang di Prpinsi Sumatera Utara. Jurnal Ilmiah Pertanian KULTURA, Vol.40 No.2.

Simchi-Levi, D. K.-L. (2003). Designing and Managing The Supply Chain : Concepts, Strategies, and Case Studies. New York: McGraw-Hill.

Soekartawi. (1994). Pembangunan Pertanian. Jakarta: PT. Raja Grafindo Persada Jakarta.

Sopiah, S. E. (2010). Metodologi Penelitian Pendekatan Praktis dalam Penelitian. Yogyakarta: C.V ANDI OFFSET.

Sugiyono, P. D. (2011). Metode Penelitian Kuantitatif Kualitatif dan R\&D. Bandung: Alfabeta.

Tunggal, D. A. (2008). DASAR-DASAR Manajemen Logistik dan Supply Chain Management. HARVARINDO.

Van der Vorst, J. (2006). Performance Measurement in Agrifood Supply Chain Networks. Quatifying the agri-food supply chain/Ondersteijn, dr.ir.C.J.M Wijnads, ir. J.H.M, Huirne, prof.dr.ir R.B.M, Kooten, van prof.dr.O.,-Dordecht : Springer/Kluwer, (Wageningen UR Frontis series 15).

Van der Vorst, J. Z. (2005). A Modeling Framework for Analyzing Supply Chain Scenarios. Applications in Food Industry, Decision Sciences 36:65-95. 